\title{
Faculty Perception toward Online Education in a State College in the Philippines during the Coronavirus Disease 19 (COVID-19) Pandemic
}

\author{
Rome B. Moralista ${ }^{1}$, Ryan Michael F. Oducado ${ }^{2, *}$ \\ ${ }^{1}$ Faculty of Business Management, Guimaras State College, Philippines \\ ${ }^{2}$ Faculty of Nursing, West Visayas State University, Philippines
}

Received June 29, 2020; Revised July 27, 2020; Accepted September 11, 2020

\section{Cite This Paper in the following Citation Styles}

(a): [1] Rome B. Moralista, Ryan Michael F. Oducado, "Faculty Perception toward Online Education in a State College in the Philippines during the Coronavirus Disease 19 (COVID-19) Pandemic," Universal Journal of Educational Research, Vol. 8, No. 10, pp. 4736 - 4742, 2020. DOI: 10.13189/ujer.2020.081044.

(b): Rome B. Moralista, Ryan Michael F. Oducado (2020). Faculty Perception toward Online Education in a State College in the Philippines during the Coronavirus Disease 19 (COVID-19) Pandemic. Universal Journal of Educational Research, 8(10), 4736 - 4742. DOI: 10.13189/ujer.2020.081044.

Copyright $\bigcirc 2020$ by authors, all rights reserved. Authors agree that this article remains permanently open access under the terms of the Creative Commons Attribution License 4.0 International License

\begin{abstract}
This research determined the perception toward online education among faculty in a State College in the Philippines. This study used a descriptive online survey involving a sample of 27 faculty members. Statistical tools employed were descriptive statistics, Mann-Whitney U test, and Kruskal-Wallis test. Research findings indicated that the majority of faculty had intermediate computer competency and had no training in online teaching, with only a few having a very stable internet connection. Faculty considered online education to result in more academic dishonesty, impersonal and lack feeling compared to face-to-face classes, and difficult to manage in terms of technology. Additionally, faculty were undecided if they are in favor of online education. The faculty significantly differed whether they are in favor of online education based on age, sex, college, educational attainment, years in teaching, academic rank, level taught, and employment status. Faculty of Higher Education Institutions must be provided with continued support and training as they adapt to the new normal in the higher education landscape and as they embrace the instructional challenges brought by the Coronavirus disease 19 pandemic.
\end{abstract}

Keywords Online Education, Faculty, Higher Education, Philippines

\section{Introduction}

Coronavirus disease 19 (COVID-19) outbreak ravaging the globe has shaken the world's educational system, but at the same time it has presented both opportunities and challenges on institutions of higher learning [1]. Higher Education Institutions (HEIs) in the country and around the world must respond proactively to the disruption brought by the pandemic. In March 2020, COVID-19 has resulted in school closure in the country. Consequently, there was a radical change in education giving rise to online learning, whereby teaching is undertaken virtually on digital platforms.

However, the COVID-19 cases are still on the rise. As of June 26, 2020, the World Health Organization has recorded 9,472,473 confirmed COVID-19 cases, and the Philippine Department of Health has recorded more than 30,000 COVID-19 positive cases [2,3]. Amid COVID-19 situation, the Philippine Commission on Higher Education (CHED) prepares for the new normal in tertiary education. One of the recommendations of the CHED for State Colleges and Universities (SUCs) is the adoption of flexible learning [4]. Although according to CHED, flexible learning may not necessarily mean that instruction will be delivered purely online [5], online education is an inevitable option to decongest classrooms amid physical or social distancing protocol and help mitigate COVID-19 transmission in schools when SUCs start to open their campuses and begin 
classes again. While it may be argued that complete online modality of the instruction can be feasible [6] and even though Filipinos are among the top users of Internet worldwide [7], the lack of preparation of faculty members to conduct online classes along with the problem long before on poor internet connection in the country pose challenges in the adoption of online education in the Philippine context [8]. It is also contended that fully online education widens the educational and socioeconomic gap while unsuccessful in making education affordable [9].

Meanwhile, prior research has also shown that faculty who teach online have a more positive perception of online instruction compared to those who do not $[10,11]$. Additionally, previous studies have identified many encouraging and discouraging factors that may influence faculty motivation to teach online [12]. Understanding the views of faculty toward online education is necessary so that their concerns may be properly addressed. The voices of faculty are needed in the acceptance of new educational technology, and that will eventually contribute to the success of learning systems in academic institutions [13].

Despite developments in computer technology and the exponential growth of technological applications paving the way for online education worldwide in the recent years [14], few scholars have studied faculty readiness for online teaching [15]. There is also limited information on how online courses are perceived by faculty [16]. Moreover, there is a scarcity of published research available on faculty perception toward online education in the local setting. As a developing country, online education among many HEIs is still underway. Also, faculty perception toward online learning in a low-resource setting during the time of COVID-19 pandemic has not been well-documented. Hence, the purpose of this research was to determine the perception of higher education faculty toward online education in one State College in the Philippines during the COVID-19 outbreak. Additionally, this study aimed to determine whether or not there are significant differences in the favorability toward online education among faculty when grouped according to sex, age, college, educational attainment, years in teaching, academic rank, level taught, employment status, perceived computer competency, training in online teaching, stability of Internet connection and average daily usage of Internet.

\section{Materials and Methods}

This study utilized a descriptive, quantitative, cross-sectional research design. Twenty-seven (27) conveniently chosen faculty members in one State College in the Philippines responded to the online survey. This is more or less around $50 \%$ of the total sampled population $(\mathrm{N}=57)$ where the study was conducted. Some scholars regard $50 \%$ as an acceptable response rate, although it is acknowledged that online surveys achieved much lower response rates than paper-based surveys [17].

A 2-part questionnaire was used to gather data. The first part asked about the demographic and work-related profile of the participants and their general internet patterns. The second part measured the perception of faculty toward online education. Thirteen (13) items were adopted from Lee and colleagues' work on faculty attitudes toward online education [10]. The 13-item scale had a Cronbach's alpha of .841. The researcher added one (1) global item to determine whether faculty favor online education. It was earlier suggested that single item measures may be used to assess global constructs [18]. All items were answerable in a 5-point Liker scale format ranging from " 1 " strongly disagree to " 5 " strongly agree. The following scale was used to interpret that data 1.00-1.79 = Strongly Disagree (SD), 1.80-2.59 = Disagree (D), 2.60-3.39 = Undecided (U), 3.40-4.19 = Agree (A), 4.20-5.00 = Strongly Agree (SA).

Data were collected online using Google Form in the last week of May 2020 during the COVID-19 pandemic. This was the time when the university prepares to implement flexible learning arrangements in response to the shift in the education system to the new normal. To ensure the ethical conduct of the study, the participants were instructed that upon proceeding with the online survey, they grant consent to participate in the research voluntarily.

The data gathered were analyzed using SPSS version 23 . Frequency count, percentages, and mean were used to describe the data. Kruskal-Wallis test was performed to determine if there were statistically significant differences between two or more groups of an independent variable and Mann-Whitney $U$ test was used to compare differences between two independent groups. The result was significant if the p-value was less than .05.

\section{Results}

Table 1 shows that majority of the faculty were female (59.3\%), young aged 22 to 39 (70.4\%), Bachelor's degree holder $(44.4 \%)$, had 1 to 5 years of teaching experience (44.4\%), with Instructor academic rank (74.1\%), permanent status of employment (51.9\%), teaches in the undergraduate level (66.7\%) and from the College of Arts and Sciences (59.3\%). The majority also had intermediate computer competency level (77.8\%) and had no training in online teaching (70.4\%). Few had a very stable internet connection (14.8\%) and more than half spend an average of 1 to 5 hours on the internet daily (66.7\%). Smart or mobile phones (88.9\%) and laptops (70.4\%) were the common devices used to connect on the Internet. 
Table 1. Demographic, Work-related Profile and General Internet Patterns

\begin{tabular}{|c|c|c|}
\hline Profile & $\mathrm{f}$ & $\%$ \\
\hline \multicolumn{3}{|l|}{ Sex } \\
\hline Male & 11 & 40.7 \\
\hline Female & 16 & 59.3 \\
\hline \multicolumn{3}{|l|}{ Age } \\
\hline Older (38-57) & 8 & 20.6 \\
\hline Younger (22-39) & 19 & 70.4 \\
\hline \multicolumn{3}{|l|}{ College } \\
\hline Teacher Education & 11 & 40.7 \\
\hline Arts and Sciences & 16 & 59.3 \\
\hline \multicolumn{3}{|l|}{ Educational Attainment } \\
\hline Doctorate Degree & 8 & 29.6 \\
\hline Master’s Degree & 7 & 25.9 \\
\hline Bachelor's Degree & 12 & 44.4 \\
\hline \multicolumn{3}{|l|}{ Years in Teaching } \\
\hline 11 years and above & 8 & 29.6 \\
\hline $6-10$ years & 7 & 25.9 \\
\hline $1-5$ years & 12 & 44.4 \\
\hline \multicolumn{3}{|l|}{ Academic Rank } \\
\hline Assistant or Associate Professor & 7 & 25.9 \\
\hline Instructor & 20 & 74.1 \\
\hline \multicolumn{3}{|l|}{ Level Taught } \\
\hline Undergraduate and Graduate & 9 & 33.3 \\
\hline Undergraduate & 18 & 66.7 \\
\hline \multicolumn{3}{|l|}{ Employment Status } \\
\hline Permanent or Plantilla & 14 & 51.9 \\
\hline Contractual or Part Timer & 13 & 48.1 \\
\hline \multicolumn{3}{|l|}{ Perceived Computer Competency } \\
\hline Expert & 3 & 11.1 \\
\hline Intermediate & 21 & 77.8 \\
\hline Beginner & 3 & 11.1 \\
\hline \multicolumn{3}{|l|}{ Training in Online Teaching } \\
\hline Yes & 8 & 29.6 \\
\hline No & 19 & 70.4 \\
\hline \multicolumn{3}{|l|}{ Stability of Internet Connection } \\
\hline Very Stable & 4 & 14.8 \\
\hline Somewhat Stable & 15 & 55.6 \\
\hline Not Stable & 8 & 29.6 \\
\hline \multicolumn{3}{|l|}{ Average Internet Usage } \\
\hline 6 hours or more & 9 & 33.3 \\
\hline 1-5 hours & 18 & 66.7 \\
\hline \multicolumn{3}{|c|}{ Devices Used to Connect on the Internet* } \\
\hline Smart or mobile phone & 24 & 88.9 \\
\hline Tablet or Ipad & 3 & 11.1 \\
\hline Laptop & 19 & 70.4 \\
\hline Desktop computer & 3 & 11.1 \\
\hline
\end{tabular}

Table 2 shows that faculty were generally undecided whether they are in favor of online education $(\mathrm{M}=2.89)$.
They were also undecided if online education is a viable alternative for learning $(\mathrm{M}=3.04)$ and if the time commitment for developing online education courses is comparable to those in face-to-face classes $(\mathrm{M}=3.15)$. Additionally, faculty were undecided whether grades will be lower for students in online education class $(M=2.96)$ and if their lectures cannot be replaced by technology tools $(M=3.19)$ and if teaching online will impact their face-to-face courses and instruction $(\mathrm{M}=2.93)$. On the other hand, the faculty agreed that students learn less $(\mathrm{M}=3.52)$, that there is less student-teacher interaction $(\mathrm{M}=3.67)$ and that student discussions seem impersonal and lack feeling $(\mathrm{M}=3.85)$ in online learning environments. They also agreed that the technology of online education is difficult to manage $(\mathrm{M}=3.56)$ and that there is a high degree of depersonalization $(\mathrm{M}=3.63)$ and more academic dishonesty (cheating, plagiarism) $(\mathrm{M}=4.15)$ in online education. Also, they agreed there is no way for teachers to know if students did the reading in an online education class (M3.41). Nonetheless, they also agreed that good teaching principles will carry over from face-to-face to online education courses $(\mathrm{M}=3.59)$.

Table 2. Perception of Online Education

\begin{tabular}{|c|c|}
\hline Attitudinal Items & Mean \\
\hline \multicolumn{2}{|l|}{ Student Learning } \\
\hline $\begin{array}{l}\text { Online education is not a viable alternative for learning } \\
\text { compared to face-to-face environments. }\end{array}$ & 3.04 \\
\hline Students learn less in online education courses. & 3.52 \\
\hline $\begin{array}{l}\text { Grades will be lower for students in an online education } \\
\text { class }\end{array}$ & 2.96 \\
\hline \multicolumn{2}{|l|}{$\begin{array}{l}\text { Class Dynamics } \\
\end{array}$} \\
\hline $\begin{array}{l}\text { There is less student-teacher interaction in online learning } \\
\text { environments. }\end{array}$ & 3.67 \\
\hline $\begin{array}{l}\text { There is a high degree of depersonalization among } \\
\text { students and teachers in online education. }\end{array}$ & 3.63 \\
\hline There is more academic dishonesty in online courses. & 4.15 \\
\hline $\begin{array}{l}\text { Student discussions in online education courses will seem } \\
\text { impersonal and lack feeling compared to face-to-face } \\
\text { classes. }\end{array}$ & 3.85 \\
\hline \multicolumn{2}{|l|}{$\begin{array}{l}\text { Faculty Experience } \\
\end{array}$} \\
\hline $\begin{array}{l}\text { The time commitment for developing online education } \\
\text { courses is comparable to those in face-to-face classes. }\end{array}$ & 3.15 \\
\hline $\begin{array}{l}\text { Teaching online will have no impact on my face-to-face } \\
\text { courses and instruction. }\end{array}$ & 2.93 \\
\hline My lectures cannot be replaced by technology tools. & 3.19 \\
\hline $\begin{array}{l}\text { There is no way for teachers to know if students did the } \\
\text { reading in an online education class. }\end{array}$ & 3.41 \\
\hline $\begin{array}{l}\text { The technology of online education courses is difficult to } \\
\text { manage. }\end{array}$ & 3.56 \\
\hline $\begin{array}{l}\text { Good teaching principles will carry over from } \\
\text { face-to-face to online education courses. }\end{array}$ & 3.59 \\
\hline \multicolumn{2}{|l|}{$\begin{array}{c}\text { Favorability Toward Online Education } \\
\end{array}$} \\
\hline Overall, I am in favor of online education. & 2.89 \\
\hline
\end{tabular}

*1.00-1.79 = SD, $1.80-2.59=\mathrm{D}, 2.60-3.39=\mathrm{U}, 3.40-4.19=\mathrm{A}, 4.20-5.00$ $=$ SA.

Table 3 shows that statistical analysis using Mann-Whitney U test and Kruskal-Wallis test revealed that there was a significant difference in the favorability 
toward online education among faculty in terms of sex $(\mathrm{p}=.036)$, age $(\mathrm{p}=.019)$, college $(\mathrm{p}=.036)$, educational attainment $(\mathrm{p}=.048)$, years in teaching $(\mathrm{p}=.048)$, academic rank $(\mathrm{p}=.013)$, level taught $(\mathrm{p}=.007)$, and employment status $(p=.047)$. On the other hand, there was no significant difference in whether faculty are in favor of online education grouped according to perceived computer competency ( $\mathrm{p}=.452)$, attendance to training in online teaching $(\mathrm{p}=.354)$, stability of internet connection $(\mathrm{p}=.354)$, and average internet usage daily $(\mathrm{p}=.758)$.

Table 3. Differences in Favorability toward Online Education

\begin{tabular}{|c|c|c|}
\hline Variables & Mean Rank & p-value \\
\hline $\operatorname{Sex}^{a}$ & & $.036 *$ \\
\hline Male & 10.45 & \\
\hline Female & 16.22 & \\
\hline Age $^{a}$ & & $.019 *$ \\
\hline Older & 19.06 & \\
\hline Younger & 11.87 & \\
\hline College $^{a}$ & & $.036^{*}$ \\
\hline Teacher Education & 17.55 & \\
\hline Arts and Sciences & 11.56 & \\
\hline Educational Attainment $^{b}$ & & $.048^{*}$ \\
\hline Doctorate Degree & 19.06 & \\
\hline Master’s Degree & 13.50 & \\
\hline Bachelor's Degree & 10.92 & \\
\hline Years in Teaching $^{b}$ & & $.048^{*}$ \\
\hline 11 years and above & 19.06 & \\
\hline $6-10$ years & 13.50 & \\
\hline $1-5$ years & 10.92 & \\
\hline Academic Rank $^{a}$ & & $.013 *$ \\
\hline Assistant or Associate Professor & 19.86 & \\
\hline Instructor & 11.95 & \\
\hline Level Taught ${ }^{a}$ & & $.007 *$ \\
\hline Undergraduate and Graduate & 19.33 & \\
\hline Undergraduate & 11.33 & \\
\hline Employment Status $^{a}$ & & $.047 *$ \\
\hline Permanent or Plantilla & 16.68 & \\
\hline Contractual or Part-Timer & 11.12 & \\
\hline Perceived Computer Competency $^{b}$ & & .452 \\
\hline Expert & 9.67 & \\
\hline Intermediate & 14.19 & \\
\hline Beginner & 17.00 & \\
\hline Training in Online Teaching $^{a}$ & & .354 \\
\hline Yes & 16.00 & \\
\hline No & 13.16 & \\
\hline Stability of Internet Connection ${ }^{b}$ & & .354 \\
\hline Very Stable & 18.75 & \\
\hline Somewhat Stable & 12.87 & \\
\hline Not Stable & 13.75 & \\
\hline Average Internet Usage $^{a}$ & & .758 \\
\hline 6 hours or more & 14.31 & \\
\hline $1-5$ hours & 13.39 & \\
\hline
\end{tabular}

Mann-Whitney U test ${ }^{a}$, Kruskal-Wallis test ${ }^{b}{ }^{*} \mathrm{p}<.05$

\section{Discussion}

This study examined the perception regarding online education among faculty in a state-funded college in a developing country before the opening of classes during the COVID-19 pandemic. This study highlighted that faculty members were generally unsure if they are in favor of online education. Ambivalence during the change process is an expected response during the transition. According to Kurt Lewin's 3 Stage Change Model, transition during change is typically accompanied by feelings of hesitation and confusion [19]. The ambivalent attitude of faculty may possibly be due to the fact that while faculty seem to have concerns about online teaching and learning to include but not limited to depersonalize instruction and proliferation of academic dishonesty, faculty are left with less options as they are required to adopt the new normal of education. Even among faculty in a leading university in online and distance education in the country, it is a fairly common problem that faculty resist and are indifferent to technology integration [20]. Similarly, a review study noted that faculty expressed concerns about student success in online classes and expressed their need for technical support [21]. Correspondingly, earlier research noted that faculty have negative impressions concerning online learning authority over technology use [22] and have negative views of online learning [23]. Also, a significant number of teachers in Macedonia disagreed with changing the traditional teaching method with e-learning [24]. Another study also included institutional, interpersonal, training and technology, and cost/benefit analysis barriers to online education [25]. The finding of this research suggests that problems and challenges associated with online education must be addressed, and online courses must be carefully planned and regulated. The undesirable preconceived notions about online education commonly held by faculty must be modified or corrected to improve the views of faculty about teaching online and thereby potentially decrease their resistance to the adoption of online education [26]. Additionally, it must be remembered that the faculty's feeling of engagement in online courses was found to be related to both social and teaching presence [27]. There are certain dynamics that work well in face-to-face instruction but do not in online learning. Faculty must be provided information on how to promote student engagement even in a virtual environment.

Meanwhile, the hesitation of faculty toward online education may also be related to the fact that the majority had a somewhat stable Internet connection, and only a few faculty in this study had a very stable connection. Even among college students, Internet connectivity remains to be an issue [7]. The Philippines is known to have the worst and slowest Internet connection speed among Asia Pacific countries [28]. Poor internet connection is already a problem in the country ever since the pandemic began [8] 
until the need to shift to online education became a pressing necessity. It is recommended that faculty must be provided with robust resources and more technology infrastructure to support online education.

In this study, the majority of faculty perceived themselves to have intermediate competency in using the computer. Similarly, teachers in Turkey had medium computer literacy [29]. Within the local context, it was earlier reported there is still a need to improve and enhance the level of competency of teachers on certain skills like using complex Information, Communication and Technology (ICT) tools [30]. Consideration of computer competency is vital because it was found to be associated with enjoyment and difficulty level of web-based courses [31]. Moreover, computer exposure is also linked with teachers' attitudes toward e-learning [32].

It is also noteworthy that the majority of participants in this research had no training in online education. Online education is not the default and may not be the preferred choice of delivery of instruction in a developing country like the Philippines [8]. However, with the need to adapt to the changes in the educational landscape, it is important for faculty to be competent in their role and acquire the necessary skills to ensure that the online learning environment will be able to effectively facilitate student learning and positively impact student outcomes [33]. HEIs are confronted with a challenge to train and retool their faculty in the pedagogy of online instruction prior to the start of classes that will employ virtual education, e-learning, or flexible learning environments.

Surprisingly, it was demonstrated in this study that there was a significant difference in faculty's perception in terms of age, educational attainment, years of teaching, and academic rank. Older faculty probably also with higher education, more teaching experience, and higher academic rank tended to be more in favor of online education. This is in contrast with the findings of studies done prior to the pandemic. A study conducted in the Kingdom of Saudi Arabia found that those who were younger, had less teaching experience, and had a Bachelor's degree had a stronger e-learning perception [34]. Also, a study among Teacher Education faculty in the Philippines disclosed that younger faculty had higher competence in ICT [35]. Perhaps, in this study, older faculty members may have more experience and wisdom about online pedagogy. On the one hand, while older faculty may have reservations toward online education, they may tend to favor online education in the midst of the COVID-19 pandemic as they may be aware that they are more at risk of developing severe illness [36]. Working in the virtual environment without needing constant face-to-face interaction limits their chances of being exposed to the disease. Nonetheless, these findings may be considered by academic institutions in planning for online education to ensure the effective implementation of online instruction at the times of COVID-19 pandemic and achieve a successful transition and transformation to e-learning [37].

This study has several limitations and further research is necessary. The cross-sectional manner of data collection prevents the tracking of changes in the perception of faculty over time. Also, this study was conducted via an online survey with a limited response rate and a relatively limited sample size. These issues constrain representativeness and generalizability of findings. The findings of the study are preliminary. Caution is warranted when using the research findings. Nonetheless, the outcome of this research can be used as an input in framing educational plans of the college during its transition to the new normal in education.

\section{Conclusions}

Faculty perceived several difficulties and challenges in the online education setting. Uncertainty defines faculty perception toward online education during the pandemic outbreak as they are called to shift to a new normal or non-traditional mode of delivery of instruction. Moreover, in contrast with researches conducted about online education before the pandemic, this study found that compared to younger faculty, older faculty reasonably having more experience tend to favor online education in the midst of COVID-19 pandemic as they may be aware that risk for severe COVID-19 illness increases with age. Despite some reservations, HEIs faculty are expected to step out of the traditions of residential face-to-face education. As faculty transit and adapt to the new normal in the higher education landscape, they must be afforded with continued support, training, and development and be provided with ways to more fully understand and expand the opportunities that online education presents. Additionally, faculty must learn to embrace the educational challenges brought by the COVID-19 pandemic and view online teaching and learning as an inviting challenge.

\section{Acknowledgements}

We are very grateful to our participants for their participation in this study.

\section{REFERENCES}

[1] Toquero, C. M. (2020). Challenges and opportunities for higher education amid the COVID-19 pandemic: The Philippine context. Pedagogical Research, 5(4), em0063. https://doi.org/10.29333/pr/7947

[2] World Health Organization. (2020). WHO coronavirus disease (COVID-19) dashboard. Available at https://covid19.who.int/?gclid=EAIaIQobChMI56js16yh6g IVlK2WCh2JygagEAAYASAAEgLj1fD_BwE 
[3] Philippine Department of Health. (2020). Updates on Covid-19. Available athttps://covid19.healthypilipinas.ph/u pdates-covid

[4] Baccay, O.T. (2020). CHED encourages SUCs to adopt flexible learning mode. Philippine Information Agency. Available at https://pia.gov.ph/news/articles/1042458

[5] San Juan, A.D. (2020). CHED: ‘Flexible learning’ not purely online; aims to decongest classrooms amid physical distancing protocol. Manila Bulletin. Available at https://news.mb.com.ph/2020/05/11/ched-flexible-learningnot-purely-online-aims-to-decongest-classrooms-amid-phys ical-distancing-protocol/

[6] Cahapay, M.B. (2020). Rethinking education in the new normal post-COVID-19 era: A curriculum studies perspective. Aquademia, 4(2). https://doi.org/10.29333/aqu ademia/8315

[7] Oducado, R.M.F. (2019). Gen Z nursing students' usage, perception and satisfaction with Facebook for educational purposes: Tool for learning or distraction. Indonesian Nursing Journal of Education and Clinic, 4(1), 79-89. http://dx.doi.org/10.24990/injec.v4i1.241

[8] Cuaton, G.P. (2020). Philippines higher education institutions in the time of COVID-19 pandemic. Revista Românească pentru Educaţie Multidimensională, 12(1), 61-70.

[9] Protopsaltis, S., \& Baum, S. (2019). Does online education live up to its promise? A look at the evidence and implications for federal policy. Center for Educational Policy Evaluation. Available at http://mason.gmu.edu/ spr otops/OnlineEd.pdf

[10] Lee, J., March, L., \& Peters, R. (2015). Faculty training and approach to online education: Is there a connection? American University Center for Teaching, Research \& Learning. Available at Retrieved from https://edspace.american.edu/online/wp-content/uploads/sit es/504/2016/03/FacultyTrainingAndApproachToOnlineEdu cation.pdf

[11] National Communication Association. (2019). Faculty attitudes on technology. Available at https://www.natcom.o rg/sites/default/files/publications/NCA_CBrief_Vol9_1.pdf

[12] Shreaves, D. (2019). Faculty perceptions of online teaching at a mid-sized liberal arts university in the Pacific Northwest: A mixed methods study (Doctoral Dissertation). Boise State University, Idaho.

[13] Farhan, W., Razmak, J., Demers, S., \& Laflamme, S. (2019). E-learning systems versus instructional communication tools: Developing and testing a new e-learning user interface from the perspectives of teachers and students. Technology in Society, 59, 101192. https://doi.org/10.1016/j.techsoc.20 19.101192

[14] Abraham, S.E. (2014). Online education: Perceptions of faculty and administrators at three different types of institutions of higher education (Doctoral Dissertation). East Tennessee State University, Tennessee.

[15] Martin, F., Budhrani, K., \& Wang, C. (2019). Examining faculty perception of their readiness to teach online. Online Learning, 23(3), 97-119. http://dx.doi.org/10.24059/olj.v23 i3.1555
[16] Otter, R.R., Seipel, S., Graeff, T., Alexander, B., Boraiko, C., Gray, J., Petersen, K., \& Sadler, K. (2013). Comparing student and faculty perceptions of online and traditional courses. The Internet and Higher Education, 19, 27-35. https://doi.org/10.1016/j.iheduc.2013.08.001

[17] Nulty, D.D. (2008). The adequacy of response rates to online and paper surveys: what can be done?. Assessment \& Evaluation in Higher Education, 33(3), 301-314. https://doi.org/10.1080/02602930701293231

[18] Wanous, J.P., Reichers, A.E., \& Hudy,M.J. (1997). Overall job satisfaction: How good are single-item measures? Journal of Applied Psychology, 82,247-252. https://doi.org/10.1037/0021-9010.82.2.247

[19] Palma, J.A.F.S., Oducado, R.M.F., \& Palma, B.S. (2020). Continuing professional development: Awareness, attitude, facilitators, and barriers among nurses in the Philippines. Nursing Practice Today, 7. https://doi.org/10.18502/npt.v7i 3.3348

[20] Arinto, P.B. (2016). Issues and challenges in open and distance e-learning: Perspectives from the Philippines. International Review of Research in Open and Distributed Learning, 17(2), 162-180.

[21] Wingo, N. P., Ivankova, N.V., \& Moss, J.A. (2017). Faculty perceptions about teaching online: Exploring the literature using the technology acceptance model as an organizing framework. Online Learning, 21(1), 15-35. http://dx.doi.org/10.24059/olj.v21i1.761

[22] Haidar, N.A. (2014). Perceptions of higher education online learning faculty in Lebanon (Doctoral Dissertation). Walden University, Minnesota.

[23] Willett, J., Brown, C., \& Danzy-Bussell, L. A. (2019). An exploratory study: Faculty perceptions of online learning in undergraduate sport management programs. Journal of Hospitality, Leisure, Sport \& Tourism Education, 25, 100206. https://doi.org/10.1016/j.jhlste.2019.100206

[24] Xhaferi, G., Farizi, A., \& Bahiti, R. (2018). Teacher'attitudes towards e-learning in higher education in Macedonia Case study: University of Tetovo. European Journal of Electrical Engineering and Computer Science, 2(5), 14-17. http://dx.doi.org/10.24018/ejece.2018.2.5.26

[25] Lloyd, S.A., Byrne, M.M., \& McCoy, T.S. (2012). Faculty-perceived barriers of online education. MERLOT Journal of Online Learning and Teaching, 8(1), 1-12.

[26] Felege, C. \& Olson, M. (2015). Online education: Faculty perceptions and recommendations. Focus on Colleges, Universities, and Schools, 9(1), 1-9.

[27] Gonzalez, M., \& Moore, N. (2020). A comparison of faculty and graduate students' perceptions of engaging online courses: A mixed-method study. International Journal of Educational Methodology, 6(1), 223-236. https://doi.org/10 $.12973 /$ ijem.6.1.223

[28] The Manila Times. (2018). PH's economic competitiveness: is slow Internet a factor? Available at https://www.manilatimes.net/2018/06/03/business/phs-econ omic-competitiveness-is-slow-internet-a-factor/403610/\#: : text=The\%20Philippines'\%205.5\%20Mbps\%20average,the \%20slowest\%20at\%201.4\%20Mbps. 
[29] Konan, N. (2010). Computer literacy levels of teachers. Procedia Social and Behavioral Sciences, 2(2), 2567-2571. https://doi.org/10.1016/j.sbspro.2010.03.374

[30] Marcial, D.E., \& de la Rama, P.A. (2015). ICT competency level of teacher education professionals in the entral Visayas Region, Philippines. Asia Pacific Journal of Multidisciplinary Research, 3(5), 28-38.

[31] Du, Y. (2004). The relationship between students' computer competency and perception of enjoyment and difficulty level in web-based distance learning. Education Libraries, 27(2), 5-12. http://dx.doi.org/10.26443/el.v27i2.201

[32] Kisanga, D. (2016). Determinants of teachers' attitudes towards e-learning in Tanzanian higher learning institutions. International Review of Research in Open and Distributed Learning, 17(5), 109-125.

[33] Frazer, C., Sullivan, D.H., Weatherspoon, D., \& Hussey, L. (2017). Faculty perceptions of online teaching effectiveness and indicators of quality. Nursing Research and Practice,
Article ID 9374189. https://doi.org/10.1155/2017/9374189

[34] Alenezi, A.M. (2012). Faculty members' perception of e-learning in higher education in the Kingdom of Saudi Arabia (KSA) (Doctoral Dissertation). Texas Tech University, Texas.

[35] Pardo, C.G. (2012). Information and communication technology competence of the University of Northern Philippines-college of teacher education faculty. UNP Research Journal, 21, 110-126.

[36] Centers for Disease Control and Prevention. Coronavirus disease 2019 (COVID-19). Available at https://www.cdc.go v/coronavirus/2019-ncov/need-extra-precautions/older-adul ts.html

[37] Guillasper, J.N., Soriano, G.P., \& Oducado, R.M.F. (2020). Psychometric properties of 'attitude towards e-learning scale' among nursing students. International Journal of $\begin{array}{lll}\text { Educational Sciences, } & 30(1-3), & 1-5 .\end{array}$ https://doi.org/10.31901/24566322.2020/30.1-3.1135 